\title{
VIENNA RADIUM INSTITUTE RADIOCARBON DATES IX
}

\section{HEINZ FELBER}

Institut für Radiumforschung und Kernphysik der Österr Akademie der Wissenschaften, Vienna, Austria

Measurements have continued with the same proportional counter system, pretreatment procdure, methane preparation, measurement, and calculation, as described previously ( $R, 1970$, v 12, p 298-318). Uncertainties quoted are single standard deviations originating from standard, sample, background counting rates and half-life. No ${ }^{13} \mathrm{C} /{ }^{12} \mathrm{C}$ ratios were measured. mitters.

Sample descriptions have been prepared in cooperation with sub-

\section{ACKNOWLEDGMENTS}

I express my thanks to Ing L Stein for excellent work in sample preparation, and to $\mathrm{K}$ Flandorfer for careful operation of the dating equipment.

\section{SAMPLE DESCRIPTIONS}

I. GEOLOGY, GLACIOLOGY AND BOTANY

\section{A. Austria}

VRI-569. Altenwörth, Nö

$7320 \pm 110$

Split oak stem, with root stock, $10 \mathrm{~m}$ long, $60 \mathrm{~cm}$ diam, fossil drift wood of $\mathrm{R}$ Danube, overlain by $4 \mathrm{~m}$ gravel, left bank $1 \mathrm{~km}$ downstream from dam of Sta Altenwörth $\left(48^{\circ} 23^{\prime} \mathrm{N}, 15^{\circ} 52^{\prime} \mathrm{E}\right)$, Lower Austria. Coll 1976 and subm by Henriette Meissinger, Schiffahrtsmuseum Spitz/Donau, Nö.

VRI-571. St Pölten, Nö

$$
3830 \pm 90
$$

Oak stem at 5 to $6 \mathrm{~m}$ depth in gravel of $\mathrm{R}$ Traisen, pit Paderta, Viehofen near St Pölten (48 $13^{\prime}$ N, $15^{\circ} 38^{\prime}$ E), Lower Austria. Coll 1976 and subm by Heinrich Fischer, Vienna.

\section{VRI-516. Strobl, Oö}

Peat from depth 2.20 to $2.35 \mathrm{~cm}$ of bog Moosalmmoor near Lake Schwarzensee $\left(47^{\circ} 46^{\prime} \mathrm{N}, 13^{\circ} 29^{\prime} 10^{\prime \prime} \mathrm{E}\right)$, near Strobl, Upper Austria. Coll and subm by $\mathrm{D}$ van Husen, Geol Inst, TU Vienna. Comment (DvH): dates 1st increase of Fagus-Abies in pollen diagram.

\section{Seefeld series, Ö̈}

Organic samples in boring cores coll from different depths near pump sta in Seefeld $\left(47^{\circ} 50^{\prime} \mathrm{N}, 13^{\circ} 33^{\prime} \mathrm{E}\right)$, Lake Attersee, OÖ. Coll 1975 and subm by Helmut Flögl, Reinhaltungsverband Attersee, Schörfling, Oö.

General Comment (HF): exploration of soil chronology suggested by landslide.

VRI-543. 930 to $960 \mathrm{~cm}$

Wood splinters and remnants of leaves from depth 930 to $960 \mathrm{~cm}$. 
VRI-544. 740 to $930 \mathrm{~cm}$

Piece of branch in core between 740 to $930 \mathrm{~cm}$.

\section{Mt Dachstein series, Oö}

Brown-moss-Dy of postglacial organic lacustrine deposition within doline: Lake Hirzkarsee, Mt Dachstein $\left(47^{\circ} 31^{\prime} \mathrm{N}, 13^{\circ} 41^{\prime} \mathrm{E}\right), 1800 \mathrm{~m}$ alt, Upper Austria. Coll 1977 and subm by Roland Schmidt, Limnolog Inst Österr Akad Wiss, Vienna.

General Comment (RS): dates postglacial climatic oscillation palynologically detected. No humic acids separation.

VRI-604. Hirzkarsee, 100 to $115 \mathrm{~cm} \quad 8210 \pm 150$ high.

Sample from depth 100 to $115 \mathrm{~cm}$. Comment (RS): age unexpectedly

\section{VRI-605. Hirzkarsee, 120 to $135 \mathrm{~cm}$}

$9380 \pm 140$ high.

Sample from depth 120 to $135 \mathrm{~cm}$. Comment (RS): age unexpectedly

\section{VRI-492. Totes Gebirge, Steiermark}

$31,200 \pm 1100$

Pollen, spores, and plant detritus 15 to $20 \mathrm{~cm}$ below ground surface of Graf-Kesselstadt-Dom, Salzofenhöhle cave $\left(47^{\circ} 40^{\prime} 45^{\prime \prime}\right.$ N, $31^{\circ} 35^{\prime} 45^{\prime \prime}$ E), Totes Gebirge, Styria. Coll 1967, prepared and subm by Ilse Draxler, Geol BA, Vienna. Comment (ID): dates cave bear layer. Already known dates: GRO-761, 34,000 \pm 3000 , charcoal from cultural layer in entrance hall; GRO-N-4628, $>44,500$, bones from entrance hall.

VRI-508. Ödensee, Steiermark

$10,160 \pm 130$

Peat from bog NNE lake Ödensee between Kame terrace and end moraine $\left(47^{\circ} 34^{\prime} 08^{\prime \prime} \mathrm{N}, 13^{\circ} 49^{\prime} 36^{\prime \prime} \mathrm{E}\right)$, Styria. Coll 1974 from depth 405 to $415 \mathrm{~cm}$ and subm by $\mathrm{D}$ van Husen. Comment $(\mathrm{DvH})$ : dates palynologically established climatic deterioration.

\section{Mitterndorfer Becken series, Steiermark}

Samples from different depths of bog between Kame terrace and end moraine ridge NE lake Ödensee $\left(47^{\circ} 33^{\prime} 45^{\prime \prime} \mathrm{N}, 13^{\circ} 50^{\prime} 20^{\prime \prime} \mathrm{E}\right)$, Mitterndorfer Becken, Styria. Coll and subm by D van Husen.

General Comment (DvH): dates palynologically detected events. No humic acid separation $(\mathrm{HF})$.

VRI-513. 395 to $405 \mathrm{~cm}$

$6610 \pm 110$

Peat 395 to $405 \mathrm{~cm}$ below surface. Comment (DvH): dates immigration of copper-beech.

VRI-514. 180 to $200 \mathrm{~cm}$

$3180 \pm 90$

Peat 180 to $200 \mathrm{~cm}$ below surface. Comment (DvH): dates beginning of Carpinus and culture pollen. 
VRI-515. Base

$$
11,500 \pm 180
$$

Gyttja and peat from base. Comment (DvH): dates beginning of peat growth coinciding with slope of Pinus max.

\section{Stubaital series, Tirol}

Peat from different horizons of Buntes Moor bog $\left(46^{\circ} 59^{\prime} 27^{\prime \prime} \mathrm{N}, 11^{\circ}\right.$ $08^{\prime} 45^{\prime \prime}$ E), Fernauferner glacier, $2285 \mathrm{~m}$ alt, Stubai Valley, Tyrol. Coll 1976 and subm by Gernot Patzelt, Geog Inst, Univ Innsbruck.

General Comment (GP): dates glacier oscillations.

VRI-456. 82 to $84 \mathrm{~cm}$

$$
620 \pm 80
$$

Peat, depth 82 to $84 \mathrm{~cm}$, from undermost $2 \mathrm{~cm}$ of peat band $11 \mathrm{~cm}$ thick overlying loam sediment. Comment (GP): dates end of glacial max. Unknown origin of unacceptable young age.

VRI-457. 73 to $75 \mathrm{~cm}$

$1270 \pm 70$

Peat, depth 73 to $75 \mathrm{~cm}$, from uppermost $2 \mathrm{~cm}$ of same layer as VRI456. Comment (GP): dates beginning of glacier max.

VRI-458. 45 to $47 \mathrm{~cm}$

$$
450 \pm 70
$$

Peat, depth 45 to $47 \mathrm{~cm}$, from uppermost $2 \mathrm{~cm}$ of $8 \mathrm{~cm}$ thick peat layer. Comment (GP): dates beginning of glacier max.

VRI-459. 34 to $35 \mathrm{~cm}$

$$
\mathbf{5 3 0} \pm \mathbf{7 0}
$$

Peat, depth 34 to $35 \mathrm{~cm}$, from 1 to $2 \mathrm{~cm}$ thick peat layer in loamy washed in sediments. Comment (GP): dates end of same (VRI-458) glacier $\max$.

VRI-460. 17 to $19 \mathrm{~cm}$

Peat, depth 17 to $19 \mathrm{~cm}$, from peat layer $2 \mathrm{~cm}$ thick in loamy washed in sediments.

VRI-526. 72 to $76 \mathrm{~cm}$

$$
1200 \pm 150
$$

Peat, depth 72 to $76 \mathrm{~cm}$, same horizon as VRI-457. Comment (GP): verifies VRI-457.

VRI-527. 103 to $108 \mathrm{~cm}$

$$
1940 \pm 150
$$

Peat, depth 103 to $108 \mathrm{~cm}$, from uppermost $4 \mathrm{~cm}$ of peat layer, 9 to $11 \mathrm{~cm}$ thick, covered by washed in loamy sediment. Comment (GP): completes series VRI-11: $1890 \pm 120$ and VRI-15: $2280 \pm 110(\mathrm{R}, 1970, \mathrm{v} 12$, p 303) sandwiching VRI-527.

\section{Sölden series, Tirol}

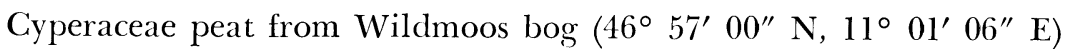
near Sölden, Tyrol. Coll 1975 and subm by Sigmar Bortenschlager, Botan Inst, Univ Innsbruck.

General Comment (SB): dates palynologically detected events. No humic acids separation. 
VRI-461. 200 to $207 \mathrm{~cm}$

$5750 \pm 110$

Peat from depth 200 to $207 \mathrm{~cm}$. Comment (SB): pollen profile indicates human influence.

VRI-462. 245 to $252 \mathrm{~cm}$

$6240 \pm 110$

Peat from depth 245 to $252 \mathrm{~cm}$. Comment (SB): pollen profile indicates lst human influence with distinct signs of woodland clearing.

VRI-463. 565 to $752 \mathrm{~cm}$

$8780 \pm 120$ curve.

Peat from depth 565 to $752 \mathrm{~cm}$. Comment (SB): dates beginning of fir

\section{Obergurgl series, Tirol}

Samples from base of undisturbed bog 200 to $215 \mathrm{~cm}$ thick, over ground moraine. Bog near Schönwieshütte shelter $\left(46^{\circ} 50^{\prime} 45^{\prime \prime} \mathrm{N}, 11^{\circ} 00^{\prime}\right.$ $18^{\prime \prime}$ E), 2260m alt, near Obergurgl, Ötz Valley, Tyrol. Coll 1976 and subm by Gernot Patzelt.

General Comment (GP): samples completing Schönwies series VRI-230 (R, 1972, v 14, p 501), VRI-296-299 (R, 1974, v 16, p 279), date beginning of vegetational development in surroundings of bog and give min age for ice retreat.

VRI-528. Schönwies 6

$9300 \pm 300$

Wood remnants.

VRI-529. Schönwies 7

$9590 \pm 260$

Peat surrounding VRI-528.

\section{Sarnthein 1 series, Italy}

$$
\text { B. Europe, Asia }
$$

Cyperaceae peat from bogs outside of outermost end moraines of Egesen phase, Mt Villanders-Berg near Sarnthein, Italy. Coll by boring 1976 and subm by Sigmar Bortenschlager, Botan Inst, Univ Innsbruck.

General Comment (SB): dates palynologically detected events. No humic acids separation.

VRI-538. Rinderplatz 1

$$
11,790 \pm 170
$$

Peat in contact with base gravel at depth 545 to $550 \mathrm{~cm}$ from Rinderplatz bog $\left(46^{\circ} 38^{\prime} 41^{\prime \prime} \mathrm{N}, 11^{\circ} 29^{\prime} 40^{\prime \prime} \mathrm{E}\right)$. Comment (SB): dates beginning of organic sedimentation and gives min age for ice retreat in this area. Age too low.

VRI-540. Rinderplatz 2

$$
10,030 \pm 170
$$

Peat at depth 505 to $510 \mathrm{~cm}$ from Rinderplatz bog. Comment (SB): dates final reforestation in this area.

VRI-541. Rinderplatz 3

$$
8480 \pm 110
$$

Peat at depth 410 to $415 \mathrm{~cm}$ from Rinderplatz bog. Comment (SB): dates decrease of Pinus and increase of Picea curve. 
VRI-537. Malschötscher Hotter

Peat at depth 240 to $247 \mathrm{~cm}$ from Malschötscher Hotter bog $\left(46^{\circ} 39^{\prime}\right.$ $58^{\prime \prime} \mathrm{N}, 11^{\circ} 27^{\prime} 30^{\prime \prime} \mathrm{E}$ ). Comment (SB): dates beginning of organic sedimentation and gives min age for ice retreat in this area. Age $>10,000$ вр is expected.

\section{Sarnthein 2 series, Italy}

Cyperaceae peat from Dura-Bog $\left(46^{\circ} 48^{\prime} 25^{\prime \prime} \mathrm{N}, 11^{\circ} 27^{\prime} 35^{\prime \prime} \mathrm{E}\right)$, Mt Villanders-Berg near Sarnthein, Italy. Coll by boring 1976 and subm by Sigmar Bortenschlager.

General Comment (SB): dates palynologically detected events. No humic acids separation.

VRI-550. 185 to $190 \mathrm{~cm}$

Peat at depth 185 to $190 \mathrm{~cm}$. Comment (SB): dates Picea max following herbaceous pollen max.

VRI-551. 90 to $95 \mathrm{~cm}$

Peat at depth 90 to $95 \mathrm{~cm}$. Comment (SB): dates renewed increase of Pinus and 1st signs of culture.

VRI-552. 50 to $55 \mathrm{~cm}$

Peat at depth 50 to $55 \mathrm{~cm}$. Comment (SB): dates Pinus max, rise of herbaceous curve, and increase of cereals and Plantago.

VRI-554. Natz, Italy

$12,700 \pm 200$

Clay with gyttja from base of Sommersüss bog, depth 425 to $435 \mathrm{~cm}$, near Natz $\left(46^{\circ} 45^{\prime} 39^{\prime \prime} \mathrm{N}, 11^{\circ} 40^{\prime} 42^{\prime \prime} \mathrm{E}\right)$, Italy. Coll by boring 1977 and subm by Hannes Müller and Alois Seiwald, Botan Inst, Univ Innsbruck. Comment (HM): dates beginning of organic sedimentation.

\section{Canary Islands series, Spain}

Charcoal from aboriginal fire places at different alts above recent sea level, near Parador (27 $45^{\prime} \mathrm{N}, 18^{\circ} \mathrm{E}$ ), Hierro I., Canary Is., Spain. Coll 1976 and subm by Herbert Franz, Univ Bodenkultur, Vienna.

General Comment (HF): dates upper limit for last sea level max indicated by marine sediments and lava rubble reaching $2 \mathrm{~m}$ above fireplaces.

\section{VRI-564. Hierro I}

$990 \pm 110$

$9.5 \mathrm{~m}$ alt.

VRI-565. Hierro II

$1390 \pm 90$

$10 \mathrm{~m}$ alt.

VRI-566. Hierro III

$1220 \pm 90$

$10.8 \mathrm{~m}$ alt.

VRI-567. Hierro V

$980 \pm 70$

Ca $11 \mathrm{~m}$ alt, ca $100 \mathrm{~m} \mathrm{~N}$ samples I and II. 


\section{Rawcun series, Afghanistan}

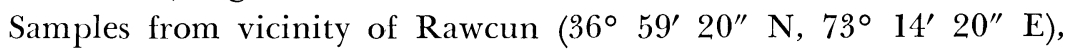
$3230 \mathrm{~m}$ alt, Wakhan Valley, Afghanistan. Coll 1975 and subm by Gernot Patzelt.

General Comment (HF): no humic acid separation.

VRI-524. Rawcun 1

$3600 \pm 80$

Wood at base of lacustrine sediment deposited by Wakhan Valley R, temporarily dammed up by alluvial cone from steep side valley. Comment (GP): dates beginning of last lake damming.

VRI-525. Rawcun 5

$1350 \pm 60$

Charcoal in burning horizon 5 to $10 \mathrm{~cm}$ thick above $90 \mathrm{~cm}$ sediment from dammed up lake and overlain by 50 to $70 \mathrm{~cm}$ fine sand from artificial irrigation followed by recent soil. Comment (GP): gives min age for end of last lake damming and max age for beginning of artificial irrigation (agriculture?).

VRI-545. Kathmandu, Nepal

$\mathbf{2 6 , 7 0 0} \pm \mathbf{8 0 0}$

Lignited wood from light gray loam horizon in steep profile wall on R Nakhu Khola S Kathmandu (26 $52^{\circ}$ N, 85 $19^{\prime}$ E), Nepal. Coll 1975 and subm by Herbert Franz. Comment (HF): dates sediments of former lake in Kathmandu basin.

VRI-506. Wadi Dawasir, Saudi Arabia

$3 \pm 0.3 \%$ modern

Calcareous crust on noncalcareous gravel $60 \mathrm{~cm}$ below surface of fluvial terrace erosion of Wadi Dawasir (20 $\left.40^{\prime} \mathrm{N}, 44^{\circ} 30^{\prime} \mathrm{E}\right)$, Saudi Arabia. Coll 1975 and subm by Josef Zötl, Hydrogeol, TU Graz. Comment (JZ): dates fluvial terrace: $26,900 \pm 900 \mathrm{BP}$ is calculated with recent value $85 \%$ modern (Münnich \& Vogel, 1959; Geyh \& Schillat, 1966), max age 28,200 $\pm 900 \mathrm{BP}$ with $100 \%$ modern.

VRI-572. Jeddah, Saudi Arabia

$17,100 \pm 300$

Fossil reef corals $5 \mathrm{~km} \mathrm{E}$ of present Red Sea shoreline N Jeddah $\left(21^{\circ}\right.$ $48^{\prime} \mathrm{N}, 39^{\circ} 06^{\prime} \mathrm{E}$ ), Saudi Arabia, following foot of N flank of SW-NE striking Quaternary basalt flow, small ridge rising ca $10 \mathrm{~m}$ above coastal plain recently. Typical example of relief inversion by marine abrasion. Coll 1976 and subm by Josef Zötl. Comment (JZ): dates high sea level phase corresponding with coral growth.

VRI-573. Harrat al Kishb, Saudi Arabia $\quad 7.3 \pm 0.3 \%$ modern

Carbonate weathering of young basalt tongue was dissolved, transported and precipitated in a recently dry basin at SE margin of Harrat al Kishb (22 $\left.40^{\prime} \mathrm{N}, 41^{\circ} 34^{\prime} \mathrm{E}\right)$, Saudi Arabia. Coll 1976 and subm by Josef Zötl. Comment (JZ): dates humid climate phase necessary for carbonate dissolution. Age 19,700 \pm 400 follows with recent activity $85 \%$ modern (Geyh \& Schillat, 1966; Münnich \& Vogel, 1959). 
Bones in Pit 107, Böheimkirchen excavation (48 $\left.18^{\prime} \mathrm{N}, 15^{\circ} 45^{\prime} \mathrm{E}\right)$ near St Pölten, Lower Austria. Coll 1974 and subm by J W Neugebauer, Inst Ur-Frühgesch, Univ Vienna. Comment (JWN): absolute dating of archaeol classified material. Verifies VRI-496 (R, v 21, no. 1, p 118). Correction for de Vries effect (Suess, 1970) gives 1500 BC. Collagen extracted by method of R Longin (1971).

\section{Hallstatt series, Oö}

Wood samples coll above, in, and below prehistoric path layer (Trampelschicht) at Place 05 of Kaiser-Josef-adit, Hallstatt salt mine $\left(47^{\circ}\right.$ $\left.34^{\prime} \mathrm{N}, 48^{\circ} 57^{\prime} 26^{\prime \prime} \mathrm{E}\right)$, Upper Austria. Coll 1975 and subm by F E Barth, Naturhist Mus, Vienna.

General Comment (FEB): clue to development of Trampelschicht.

VRI-558. Sample 1

$2990 \pm 100$ high.

Twigs above Trampelschicht. Comment (FEB): age unexpectedly

VRI-559. Sample 2

$2690 \pm 100$

Wood from Trampelschicht.

VRI-560. Sample 3

$2570 \pm 90$

Wood below Trampelschicht.

VRI-568. Antlangkirchen, Ö̈ $\quad 330 \pm 80$

Wooden pump-tube, oak, discovered in bog near Antlangkirchen $\left(48^{\circ}\right.$ $22^{\prime} \mathrm{N}, 13^{\circ} 42^{\prime} \mathrm{E}$ ), Schärding dist, Upper Austria. Coll 1956 and subm by Josef Reitinger, OÖ Landesmus, Linz. Comment (JR): fixes find chronologically. De Vries correction (Suess, 1970) gives AD 1480 to 1600.

\section{Ptukh series, Afghanistan}

$$
\text { B. Europe, Asia, Africa }
$$

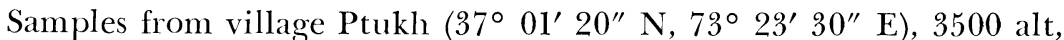
and surroundings, Wakhan Valley, Afghanistan. Coll 1975 and subm by Gernot Patzelt.

General Comment (GP): 1st chronologic exploration in this area. No humic acid separation.

VRI-523. Ptukh 1

$1880 \pm 70$

Clayey peat, base sample from -100 to $-95 \mathrm{~cm}$ of peat profile $102 \mathrm{~cm}$ deep $\left(37^{\circ} 00^{\prime} 30^{\prime \prime} \mathrm{N}, 73^{\circ} 22^{\prime} 10^{\prime \prime} \mathrm{E}\right), 3300 \mathrm{~m}$ alt, near Ptukh. Comment (GP): dates beginning of peat growth and with pollen analyses, gives insight into history of climate, vegetation, settlement, and agriculture. 
VRI-518. Ptukh 2

$\mathbf{5 3 0} \pm \mathbf{7 0}$

Charcoal, wood, and grass remains, filling material between stones of decayed irrigation channel "Old Waal" near Ptukh below silty sediments of irrigation water. Comment (GP): dates erection of irrigation system and supposed beginning of settlement in this area.

VRI-519. Ptukh 3

Stalks and roots of aquatic plants in silty sediment of destroyed artificial irrigation system "Old Waal" near Ptukh. Comment (GP): dates end of artificial irrigation system and settlement.

VRI-521. Ptukh 4

Plant remains in loam mortar of stone base of House Ruin $4 \mathrm{M}$ in Ptukh. Comment (GP): dates house bldg.

VRI-520. Ptukh 5

Like VRI-521, Ruin $1 \mathrm{M}$.

VRI-595. Luqsor, Egypt

Modern

Remains of hair and skin of horse $-1 \mathrm{~m}$ below dry sand and stone in necropolis of Theben, Luqsor, Qurna $\left(25^{\circ} 40^{\prime} \mathrm{N}, 33^{\circ} 00^{\prime} \mathrm{E}\right)$, Asasif, Egypt. Coll 1970, subm by Manfred Bietak, Österr Archäol Inst, Cairo branch. Comment (MB): dating for osteologic comparison. Preservation and location close to recent way may point to recent age. No pretreatment.

\section{Correction}

VRI-418-421, R, 1976, v 18, p 240, 241: Signs of statistical uncertainties should be exchanged.

\section{REFERENCES}

Geyh, M A and Schillat, B, 1966, Messungen der Kohlenstofflsotopenhäufigkeit von Kalksinterproben aus der Längenfelder Höhle: Aufschluss, v 17, p 315-323.

Longin, R, 1971, New method of collagen extraction for radiocarbon dating: Nature, v 230, p 241-242.

Münnich, K O, and Vogel, J, 1959, C-14-Altersbestimmungen von Süsswasser-Kalkablagerungen: Naturwiss, v 46, p 168-169.

Suess, H E, 1970, Bristlecone-pine calibration of the radiocarbon time-scale $5200 \mathrm{BC}$ to the present, in Olsson, I U, (ed), Radiocarbon variations and absolute chronology: Stockholm, Almqvist and Wiksell. 